\title{
The interpretative dimension of transformative events: Outrage management and collective action framing after the 2001 anti-G8 Summit in Genoa
}

Social Movement Studies, Published online 15 January 2015, DOI:

$10.1080 / 14742837.2014 .995076$

\section{Stefania Vicari, sv32@le.ac.uk}

\section{Department of Media and Communication, University of Leicester}

\begin{abstract}
By focusing on the aftermath of the 2001 anti-G8 summit in Genoa, this paper aims to provide a comprehensive insight into the interpretative dimension of transformative events leading to backfire. First, in line with the existing literature on transformative events, the study shows that after the violent events Italian authorities employed all possible strategies to inhibit public outrage (i.e., cover-ups of the situation, stigmatizations of targets to legitimate repressive action, reinterpretations of police violence as different from direct attacks, presence of authoritative assessments and intimidation of participants and witnesses). Second, a multidimensional scaling of symbolic devices from 70 social forum websites shows that after 2001 Italian social movement actors used the narrative of the Genoa events in deliberative (i.e., bridging, extension) or negotiating (i.e., punctuation, articulation) framing processes to build new collective action frames.
\end{abstract}

Key words: collective action frames, repression, mobilization, transformative events, Genoa Social Forum, Global Justice Movement.

According to the social movement literature, events can turn transformative when they lead to sudden increases or decreases in the levels of mobilization (see, among the others, Della Porta, 2008: 30; Hess and Martin, 2006: 249; McAdam and Sewell, 2001: 101; Sewell, 1996: 
272). Repressive events, for instance, are potentially transformative as they can ignite or trigger protest waves. When repression does increase mobilization levels, two specific processes characterize transformative events: authorities develop strategies of outrage management and social movement actors engage in new protest in response, so-called "backfire" mobilization ${ }^{1}$ (Francisco, 2004; Hess and Martin, 2006; Jansen and Martin, 2004; Martin, 2004, 2005, 2007). Public memory of transformative events is then marked exactly by "the conflict between different narratives of the past, each one struggling for a group's position inside the public sphere" (Zamponi, 2013: 2). While scholarly attention has been drawn to the interpretative dimension of authorities' strategies of outrage management (Hess and Martin, 2006; Jansen and Martin, 2004; Martin, 2004, 2005, 2007, 2009), little cognitive investigation has been devoted to social movements' countering action.

By applying a frame analysis approach to the aftermath of the 2001 anti-G8 summit in Genoa, this study aims exactly to fill this lacuna and flesh out the interpretative dimension of both processes associated with repressive events that lead to further mobilization. The counter-summit makes a relevant case study because it was characterized by both an extremely high degree of police violence (Della Porta and Reiter, 2006) and extensive national and international media coverage. Moreover, it was followed by increased mobilization levels, although only in the short-term, among Italian movement actors (Reiter et al., 2007). In sum, by drawing upon framing theory, this work will provide an insight into the cultural dimension of the relationship between repression and mobilization.

In the following sections, the paper will briefly introduce theoretical contributions on the linkage between repression and mobilization. Then, it will turn to social movement framing to show how the analysis of framing dynamics could enrich research on transformative events leading to new waves of mobilization. Next, the case study will be introduced. After describing data and methods, the article will develop in two main parts. The first part will 
provide the narrative of the Genoa events. The second part will directly address the interpretative processes associated with the Genoa counter-summit as a transformative event.

\section{Repression and Mobilization}

Earl (2011: 267) suggests that research on the relationship between repression and mobilization differs in whether the effects of repressive events are examined at the micro-, meso-, or macro-level. Micro-level research shows that repression, especially when perceived as illegitimate, can lead to radicalization, i.e., it can bolster individuals' willingness to join radical protest action. Meso-level analyses show that repressive events seem likely to generate alliances or splintering among and within protest groups. Finally, macro-level research - namely, longitudinal analyses of protest rates - focuses on how repression can stimulate new waves of mobilization, in particular as the aftermath of specific repressive events, i.e., when repression is perceived as extremely unjust by the general public and when information about the events is communicated to receptive audiences (Hess and Martin, 2006: 249; Jasper, 1997, 2010; Martin, 2004, 2005; Ortiz, 2007: 222). Two central processes are associated with transformative events of this sort: the management of outrage by authorities and the countering actions from social movements.

Concerning outrage management, Martin and colleagues have identified a specific set of standard interpretative tactics adopted by state authorities: cover-ups of the situation, stigmatizations of targets to legitimate repressive action, reinterpretations of repressive events as different from direct attacks, presence of authoritative assessments and intimidation of participants and witnesses (Hess and Martin, 2006; Jansen and Martin, 2004; Martin, 2004, 2005, 2007, 2009). Concerning social movements' countering actions, studies on backfire mobilization have drawn attention to the way in which harsh repression generates new mobilization (Francisco, 2004; Hess and Martin, 2006; Martin, 2006). However, the interpretative dimension of such backfire mobilization has so far been overlooked. In other 
words, while efforts have been made to identify authority-led interpretations of repressive events, little has been done to similarly investigate the development of social movements' counter-interpretations during backfire mobilization.

\section{Social Movement Framing}

The most sustained attention to the interpretative dimension of mobilization has come from research interested in frames and framing processes. Taken from a framing angle, social movements are collective actors mobilizing discourses of protest, or so-called "collective action frames": "action-oriented sets of beliefs and meanings that inspire and legitimate the activities and campaigns of a social movement organization' (Benford and Snow, 2000: 614). Collective action frames may develop in the most different contexts (e.g., democratic or totalitarian countries) and diffuse via different strategic dynamics (McCammon et al., 2008: 1110).

Studies interested in the politics of collective memory have also added to the investigation of social movements' cultural dimension. From a collective memory perspective, social movements can be seen as "agents of memory" (Jansen 2007) because they produce interpretations of past events and utilize them in present processes of mobilization. For instance, drawing attention to the rhetorical iconization of repression, McAdam describes as "critical dynamics" those events recognized and manipulated by insurgents that produce high rates of activism (McAdam, 1999: 174). The question to be answered when tackling the interpretative dimension of backfire mobilization is exactly how such manipulation takes place, or how insurgents formulate a new rhetoric of protest after a repressive event.

\subsection{From Texts to Frames: Symbolic Devices and Framing Processes}

Focusing on emergence, transformation, and development of collective action frames, Noakes and Johnston (2005: 7) underscore the importance of investigating the "cultural fabric" from which frames originate. More specifically: "If we acknowledge that frames are 
constructed from a cultural fabric and that they have a specific content, we can describe the "materials" that make them up - that is, the components of an interpretive schema" (Noakes and Johnston, 2005: 7). Therefore, if one aims to explore the "materials" of collective action frames, she needs to investigate social movements' textual production, "whether the documents of movement organizations or the spoken discourse of activists, leaders, and protest participants" (Johnston, 2005: 245). McLean suggests that "we can analyze 'strips of activity' [...] for keywords, images, and phrases that concretely construct, suggest, or evoke which frame of meaning is in effect at a given time" (1998: 55).

According to Gamson and Lasch (1983: 399) and Gamson and Modigliani (1987: 143; 1989 : 3), frames are displayed through combinations of "symbolic devices," i.e., content elements used to activate interpretative processes (see also Pan and Kosicki, 1993: 70). But what is it that one needs to look for in symbolic devices to uncover framing dynamics?

Benford and Snow identify two main sets of overlapping processes in the development, generation, and elaboration of collective action frames: discursive and strategic or alignment $(2000: 623-627)^{2}$ (see Table 1). Discursive processes entail an interactive negotiation among movement members prior to and during protest action. As discursive processes, articulation and punctuation provide the first steps for the formulation of political ideas (Gamson, 1992). Benford and Snow (2000: 623) describe frame articulation as involving "the connection and alignment of events and experiences so that they hang together in a relatively unified and compelling fashion". The attention is here drawn to the way in which different elements of a given reality are "assembled, collated, and packaged", generating a new perspective within a social movement's grievance. Gamson (1992), for example, studied frame articulation by investigating how people frame political discourse combining personal experience, cultural elements, and media content. Frame punctuation highlights and accents specific issues, themes, or beliefs. Movement slogans like "Another world is possible" or "We are the 99\%", 
for instance, illustrate this process.

Strategic or alignment processes include practices with a deliberative and utilitarian nature. Snow et al. (1986: 467-476) identify four strategic efforts for a movement organization to align its interests to prospective resource providers: frame bridging, frame amplification, frame extension, and frame transformation. Frame bridging involves the combination of elements salient to different social actors. An example of frame bridging can be found in the Global Justice Movement of the early 2000s, when different groups, organizations, and movements, joined forces by bridging their individual, often issue-based, frames. Frame amplification involves the invigoration of an existing value or belief. The human rights movement of the 1960s, for instance, engaged in activism by constantly stressing on globally recognized values like equality and liberty. Frame extension entails extending an already normalized frame to include other related issues. Snow et al (1986: 472) describe the way in which the peace movement used frame extension to attract different audiences: "The employment of rock-and-roll and punk bands to attract otherwise uninterested individuals to disarmament rallies, and the dissemination of literature explicating the services sacrificed by a community as a result of an escalating defense budget are illustrative of this practice". Finally, frame transformation provides the rationale to change old understandings and generate new ones. This happens when a social movement's frame ceases to resonate to its public, hence "new values may have to be planted and nurtured" (Snow et al 1986: 473).

\section{[Table 1 here]}

\section{The 2001 Anti-G8 Summit in Genoa}

The Genoa counter-summit became one of the central protests organized by what became known as the Global Justice Movement (GJM), a network movement opposing the neoliberal agenda brought forward by supranational institutions such as WTO, IMF, G8 and the World Bank. It received wide media exposure on both mass and new media, with public opinion 
soon focusing on the violent tactics of protest policing initially endorsed by both police and state authorities. Moreover, "Many local social forums [in Italy] developed a few months before the protest against the G8 in Genoa in order to coordinate the mobilization. In most cases, they survived and many more were formed in that year and in 2002" (Reiter et al. 2007: 60). In fact, the counter-summit contributed to the variation of mobilization levels among Italian social movement actors - in particular among local social forums - before and after July 2001.

The events at Genoa have attracted much academic attention, with scholarly work focusing on the counter-summit's organization and structure (Andretta, et al., 2002: 34-72; Reiter et al., 2007: 56-73), the internationalization of its protest (Tarrow, 2005), the emergence of new protest identities (Andretta et al., 2002: 73-106; Della Porta, 2006; Reiter et al,. 2007: 63-72), and the tactics of protest policing (Della Porta and Tarrow, 2001; Andretta et al., 2002: 107153; Della Porta et al., 2006). However, no academic work has so far investigated the 2001 anti-G8 summit in Genoa as a potential transformative event leading to both authorities' management of public outrage and framing strategies from social movement actors.

\section{Research Questions}

This article adds a cultural dimension to research interested in the relationship between repression and mobilization at the macro-level. The analysis will therefore investigate the case of the 2001 anti-G8 summit in Genoa by addressing the following research questions:

1. How does the interpretative dimension of transformative events leading to increased mobilization levels develop?

1a. How did the Italian authorities manage public outrage after the Genoa events?

1b. How did Italian social movement actors activate countering frames?

\section{Data and Methods}

By using a case history approach, I will first produce the narrative of the violent events that 
occurred at the Genoa counter-summit. This will be functional to both investigate the methods adopted by the Italian authorities to minimize public outrage and analyze the interpretative dimension of backfire mobilization.

Concerning authorities' strategies of outrage management, the analysis will rely on video documentation, historical accounts, and scholarly sociological work and draw upon the literature on transformative events. Turning to social movement framing, the investigation will focus on 70 Italian social forum websites and map the selection of symbolic devices used there to recall the Genoa narrative after July 2001. Thanks to the presence of dense social networks, friendship networks and previous membership of other organizations, social forums easily mushroomed all over Italy after the first meeting of the World Social Forum in 2001 (Della Porta 2002: 252). In fact, evidence of social forums' advocacy action could soon be found in their online networking presence (author removed 2013: 14). Since online and mobile communications have become central to Western social movements' organization and mobilization (Bennett, 2003), websites are here considered as material making up the cultural fabric of the Italian mobilization after July 2001. Social forum websites developed in the cultural context where the Genoa events took place, they were edited and maintained by social movement actors directly involved or interested in the Genoa events, and they provided the interpretative dimension of the after-Genoa mobilization in the country. The websites were retrieved in 2005. The analysis of social forums' online cultural material four years after the Genoa events allows one to evaluate the extent to which those events impacted the Italian mobilization in the short-to-medium term. In order to design a sample representative of the Italian social forum coalition, six social forums from the six main geographical areas in Italy - North-West, North-East, Centre, South, Sardinia, and Sicily were identified. The full sample was then retrieved via snowball sampling, namely following the hyperlinks from one social forum website to another. 
The sample websites were then coded in a SPSS spreadsheet according to a pre-set codebook where a variable was used to code the presence/absence of each symbolic device on each website. Drawing upon McLean (1998)'s quantitative approach to frame analysis, classical MDS was then applied first to generate a typology of symbolic devices and then to map the competing framing processes generated by different types of symbolic devices. Classical MDS involves the representation of objects - in this study symbolic devices first and social forum websites later- as points in a two-dimensional Euclidean space so that the distances between pairs of points have the strongest possible relation to the similarities among pairs. In other words, points that are close together represent similar objects, while points that are far apart represent dissimilar objects. As McLean suggests: "Measuring the use of [...] objects across cases allows us to trace which cues and framing devices are most used, the purposes to which they are put, and whether they are used in conjunction with or in contrast to other ones" (1998: 56). In sum, MDS analysis was here functional to investigate both the use of specific symbolic devices in the online realm and the implementation of competing framing processes via different types of online symbolic devices. The limitations of this method lie in its quantitative approach to cultural objects, that overlooks a more nuanced interpretation of the way in which social actors engage in specific interpretative processes. However, while delivering what may seem a crude mapping, MDS does offer useful information about different framing processes emerging from cultural material.

\section{The 2001 Anti-G8 Summit in Genoa: Narrative and Media Coverage}

\subsection{Before July 2001: Mobilization and Public Order}

The Genoa anti-G8 protest soon became a landmark in the contemporary history of social contention. Since the 1999 anti-WTO protest in Seattle - the first big demonstration organized by the GJM - research on protest policing has remarked on the gradual disintegration of the thirty-year truce between protesters and police in most Western countries (Della Porta and Tarrow 2001: 9-10; Andretta Della Porta, Mosca, and Reiter 2002: 
132-153; Tarrow 2005: 12-13; Della Porta, Reiter, and Peterson 2006). The escalation of violence at street demonstrations, started at the Seattle protest in 1999, culminated in Genoa at the 2001 anti-G8 summit, where 328 protesters, 67 police officers and 16 reporters were hospitalized (Gubitosa 2003: 177), a protestor was shot dead and over 150 jailed protesters were subjected to police brutalities while under arrest (piazzacarlogiuliani.org).

The organization of the Genoa anti-G8 protest started on December 19, 2000, when a number of Italian activist groups joined forces by signing an official document: the so-called Patto di Lavoro (Working Pact) ${ }^{3}$. Some of them had taken part in previous counter-summit demonstrations (e.g., the 1999 anti-WTO protest in Seattle; the 2000 anti-IMF protest in Prague), a few had been actively engaged in the preparation of the 2001 World Social Forum (WSF) in Porto Alegre, the first transnational gathering of global justice groups. Others were simply officially joining the protest for global justice for the first time. This Italian front became the organizational head of the Genoa Social Forum (GSF), the transnational network mobilizing for the 2001 anti-G8 summit in Genoa in July 2001.

State police, carabinieri, and financial police composed the public order divisions deployed to control the GSF protest. All the mobile divisions were authorized to use spray cans with irritant CS gas, while the use of tonfa truncheons was limited to a volunteer-based specialized unit, the "Experimental VII Nucleus," formed within the first Rome mobile division (Gubitosa, 2003: 69-74; Della Porta and Reiter, 2006: 31-32). Precautionary action was employed to prevent the arrival of known dangerous activists in Genoa, the so-called Black Block. ${ }^{4}$ These strategies were first adopted through frontier controls, which resulted in 2,093 protesters being turned away (Della Porta and Reiter, 2006: 16). A red zone, with its eight-kilometer perimeter, was defined to enclose the areas for the summit and several city streets (Della Porta and Reiter, 2006: 16). Finally, the military barracks of Bolzaneto and Forte San Giuliano were temporarily transformed into provisional prisons (Gubitosa, 2003: 
$60)$.

\subsection{July 16-22, 2001: "I fatti di Genova" (The facts of Genoa)}

The GSF network planned a six-day counter-summit, opening on July 16 with the Public Forum. The first activities were mainly run within the Diaz, Pascoli and Pertini-Diaz schools, whose rooms had been assigned to the GSF by the Genoa City and Province Councils. The protesters were also allowed to use the Pertini-Diaz school as a dormitory.

On the morning of July 20, Black Block protesters started destroying street pavements, kicking over rubbish bins and throwing stones at carabinieri at several locations (Ferrario, 2001: video; Lucarell,i 2009: video). Police forces, while chasing a group of Black Block protesters, charged into Piazza Manin, only affecting peaceful activists (Gubitosa, 2003: 192200; Della Porta and Reite, 2006: 18; Lucarelli, 2009: 23-24). In the afternoon of the same day, a rally of 15,000 people was charged by the police forces, for no apparent reason (Chiesa, 2001: 41-44), before it could even approach the yellow zone, a buffer area around the red zone. While police armored vehicles were launched at high speed after individual activists (Ferrario, 2001: video; Lucarelli, 2009: 29), a group of protesters engaged in an urban guerrilla confrontation with the police forces (for a first-person account of the clashes, see Chiesa, 2001: 44-53). In Piazza Alimonda, young protester Carlo Giuliani was hit by a bullet fired from a carabinieri Land Rover that had been surrounded by a few dozen enraged demonstrators. Giuliani fell on the ground, and his body was driven over twice by the same car as it was attempting to back away.

On July 21, the police forces, allegedly chasing Black Block protesters, charged the GSF final rally of 300,000 people (Ferrario, 2001: video; Gubitosa, 2003: 275-303; Lucarelli, 2009: 42-44), causing injuries to 133 protesters (Gubitosa, 2003: 177). During the night of the same day, the Experimental VII Nucleus, together with other police forces, was sent to the Pertini-Diaz school for a search. All of the 93 people arrested at the Pertini Diaz school, 
69 of which were severely injured and hospitalized, were later released without charge (for testimony regarding the police assault, see Gubitosa, 2003: 307-379; Lucarelli, 2009: 45-52). Overall, between the $20^{\text {th }}$ and the $22^{\text {nd }}$ of July 2001 , many people were arrested on the streets of Genoa and transferred to Bolzaneto and San Giuliano barracks. The detainees spent from several hours up to three days within these provisional prisons crowded in cells, sleeping on the floor and subjected to police brutalities (for testimony of the arrests, see Gubitosa, 2003: 408-411; Lucarelli, 2009: 34-39).

\subsection{Media Coverage and Public Response}

During the days preceding the G8 summit in Genoa, the level of public tension had gradually increased also due to a widespread diffusion of information on mass media channels. The state of general alert that came into force even before the beginning of the summit emerged for two primary reasons. On one side, mass media coverage of the preparation of the G8 summit made it evident that the approach employed by the Italian government to the demonstrations was more coercive than that in previous protests (e.g., the 2001 anti-Global Forum protests in Naples). On the other side, a few months before the summit one of the GSF leading activist groups, Tute Bianche, made public a "Declaration of War" against the G8 (Corriere della sera, May 27 2001).

The extensive media coverage of the events straight after the counter-summit was due, to a noteworthy extent, to the death of young protester Carlo Giuliani. The killing made the Genoa protest different from previous demonstrations in which police and protesters had engaged in direct confrontations. In fact, the last cases of deaths by police charges at street demonstrations in Italy dated back to the so-called anni di piombo ("years of lead"), the period of 1977-1979 (Della Porta, 1996: 70).

In sum, Italian public opinion was exposed to an extensive coverage of the events prior, during, and after the summit and the counter-summit. This exposure bolstered the emergence 
of a mixed response of the public to the protests and the violent events.

\section{After the 2001 Anti-G8 Summit in Genoa: The Interpretative Dimension of}

\section{Backfire Processes}

\subsection{Inhibiting Public Outrage: Authorities'Management of the Events}

Cover-ups. Despite the extensive media coverage, both police officers and authorities tried to devise cover-ups on different occasions. Several protesters arrested on July 20 and 21 stated that their digital cameras were intentionally destroyed by police officers before the arrest. Perhaps the most relevant cover-up concerned the Pertini-Diaz and Pascoli assault on the night of July 21 . Nobody was allowed access to the building until the detainees were carried out of doors, mainly on stretchers, by the police forces (Gubitosa, 2003: 364-367). During the assault, the computers used in the GSF Media Centre were damaged, their hard drives made irrecoverable (Della Porta and Reiter, 2007: 21). These computers had been used by the GSF legal service to gather testimony regarding instances of police brutality that occurred on July 20 and 21. Video material recording the assault of the Pertini-Diaz school was also sequestered by the police (Gubitosa, 2003: 368-375).

Stigmatization of the targets. The strongest form of stigmatization was pronounced at the end of the G8 summit by the Italian government itself. During an official press conference, the then Prime Minister Silvio Berlusconi declared that there was an open collusion between violent groups and the GSF network: "The news I have been given [by the Home Secretary Claudio Scajola] tended to clarify that there was no distinction between those who engaged in violent and guerrilla events and the Global Forum [Genoa Social Forum], who instead, according to what I have been told, favored and covered their presence" (Gubitosa, 2003: 395-396).

Reinterpretation of the events. Both police and government authorities reinterpreted the "fatti di Genova" on several occasions with the aim to present police intervention as legitimate law 
enforcement. The whole Pertini-Diaz attack was entirely reinterpreted by police authorities and, at least in the first phase, by government authorities. First, the night search was justified by an alleged attack undergone by the police mobile division in front of the Pertini-Diaz school on the afternoon of July 20 . The testimony to this attack, however, is discordant. Second, immediately after the search, representatives of the upper police ranks declared that most of the activists arrested in the building showed old wounds and that the blood found on the floor had nothing to do with police beatings that occurred within the school (Gubitosa, 2003: 366-367). It was soon clear that the 69 people hospitalized after the search were all brutally beaten up by the police within the Pertini-Diaz school. Third, two Molotov cocktails were said to have been found in the school. It took a year to discover that the police themselves had planted those two Molotov cocktails (collected elsewhere in Genoa on July 21 ) in the building to produce false evidence against those arrested (Della Porta and Reiter, 2006: 21).

Authoritative assessments. On August 1, 2001, given the national and international reactions to the "fatti di Genova," a Parliamentary Investigative Commission was constituted. At its closure, the right-wing parliamentary majority presented a statement according to which the G8 had been successful, and incidents were only due to organizational problems. The parliamentary opposition presented two more critical statements. The investigation's most relevant outcome was the removal of three high-level police officers from their positions. ${ }^{6}$ In reality, the three policemen were all promoted to higher positions within the State police (Gubitosa, 2003: 419-421). ${ }^{7}$ The inquiry into Giuliani's death was closed in May 2005; it concluded that Placanica, one of the three carabineri riding in the Land Rover, fired in selfdefense. According to the investigation, the bullet, fired in the air, hit a flying stone, which diverted its trajectory towards Giuliani. ${ }^{8}$ A Parliamentary Inquiry Commission, endowed with more power than a Parliamentary Investigative Commission and a wider spectrum than 
the individual trials, was, however, never constituted ${ }^{9}$.

Intimidations. The most striking cases of intimidation occurred within the Bolzaneto barracks. The arrested were not allowed to contact their families or speak with lawyers. Not only the detainees but also the penitentiary staff stated that the prisoners were beaten up, threatened with sexual abuse and forced to sing racist, homophobic, and fascist songs (Della Porta and Reiter, 2006: 21). In conclusion, during and after the Genoa counter-summit, government and police authorities used all the standard methods to inhibit and forestall public outrage.

\subsection{Strategic Reaction: Social Forums' Framing of the Events}

\subsubsection{A Typology of Symbolic Devices on Social Forum Websites}

In 2005, 7 out of 10 Italian social forum websites still mentioned the "fatti di Genova" in their webpages.

\section{[Table 2 about here]}

Table 2 shows the full listing of symbolic devices, i.e., website content units recalling the narrative of the Genoa events, retrieved in the sample websites. Social forum websites reported press reviews, open letters from Carlo Giuliani's parents, open letters for Carlo Giuliani, adverts about the release or the public display of documentaries on the protest, comments on the events by witnesses, editorials on the GSF protest, editorials on after-GSF events, announcements of commemorative events in the name of Carlo Giuliani, photos, and entire sections dedicated to the conduct of the police. Moreover, social forum websites often linked to four specific sources to recall the Genoa events 1) Pillola Rossa (www.piazzacarlogiuliani.org), a blog originated in December 2002 to gather articles, photos, official documents and comments on Giuliani's death; 2) Comitato Verità e Giustizia per Genova (www.veritagiustizia.it), a civic association founded in 2002 to collect funds to protect the victims of police repression at the Genoa counter-summit and provide information 
on the ongoing inquiries; 3) Supporto Legale (www.supportolegale.org), run by the Genoa Legal Forum, a group of Italian and international lawyers working on the Genoa trials; and 4) the "Genoa feature" of Indymedia (www.indymedia.org), the independent media center founded in 1999 to provide independent coverage of anti-WTO protests.

Finally, several Italian social forums also mentioned the Genoa events in their Declaration of Intents. For instance, on the Genzano Social Forum's website, one could read "Many of us took part in the Genoa days. We all know what happened. We came back with the awareness that our most elementary democratic rights, human rights, had been systematically violated. [...] What made us join forces was fear: fear to see our rights as citizens of a democratic country disappear" (Genzano Social Forum). Others stated they were born immediately after the GSF protest (Pisa Social Forum, Roma Nord Est Social Forum, Vicenza Social Forum) or mentioned the power of the GSF protest (Messina Social Forum; Valdarno Social Forum). Now, it is interesting to look at which symbolic devices were most likely to be combined on social forum websites. More specifically, by applying MDS, a spatial image of the distance between the different symbolic devices used to recall the Genoa events can be generated. The calculated distance is a function of how symbolic devices were distributed across the forum websites, that is, symbolic devices co-occurring in the same website are placed close together; symbolic devices mostly used in different websites are placed apart. On one hand, this mapping allows one to generate a typology of symbolic devices on the basis of their use in social forum websites. On the other hand, considering that different types of symbolic devices produce different framing processes, the generated typology can provide information on the range of framing processes activated by different social forum websites.

[Figure 1 about here]

Looking at Figure 1 one can conclude that symbolic devices strongly linking the narrative of the Genoa events to social forum activities were frequently used together (top quadrants). 
Those symbolic devices built a strong and direct connection between the Genoa narrative and forum activities, and, as such, we may assume that they bolstered framing processes with utilitarian and deliberative nature. First, statements recalling the Genoa events in the forums' foundation page, or Declaration of Intents, were likely to co-occur (top left quadrant). In these cases, the degree of relatedness to the GSF was made explicit by the inclusion of the Genoa narrative in the social forum's core cultural fabric. Second, outlinks to official external entities dealing with the Genoa trials (i.e., Comitato Verità e Giustizia, Piazza Carlo Giuliani, Supporto Legale, Indymedia) also tended to be employed together (top right quadrant). Those sources played a central role in building up the credibility of the discussion on the Genoa events because they entirely focused on the outcomes of police violence and on the Genoa trials.

Looking at the bottom quadrants of Figure 1, one can conclude that they are populated by symbolic devices that weakly link the narrative of the Genoa events to social forum activities. These symbolic devices seem to provide an interactive negotiation in the construction of semantic linkages between the Genoa events and social forum activities. First, internal editorials (e.g., articles focused on police violence, on protest tactics, on the GSF) - also frequently combined (bottom-left quadrant) - provided first-person views of the events, focusing on different sides of the protest. However, the degree of relatedness with the Genoa events here was less explicit because it was not included in the social forums' Declaration of Intents or foundation page. Second, external comments to the events (e.g., press reviews, open letters) - also likely to be employed together (bottom right quadrant) again represented a less explicit engagement with the Genoa narrative than in the first two cases because the discussion was entirely left to external, often non-authoritative sources of information.

Hence, looking at the mapping of Figure 1, one can draw a typology of at least four different 
types of symbolic devices leading to as many framing processes. More specifically, the vertical axis can be interpreted as measuring differences in the degree of direct engagement with the GSF protest - and deliberative versus negotiating framing processes, while the horizontal axis can be interpreted as measuring the employment of internal versus external sources of information, meaning content units produced by the forum itself versus content units borrowed from external social actors (e.g., organizations, individuals).

\subsubsection{From Symbolic Devices To Framing Processes}

The MDS of Figure 1 broadly displays the ways in which Italian social forums integrated the narrative of the Genoa events in their cultural fabric via using four different types of symbolic devices generating four competing framing processes: deliberate framing based on the inclusion of the Genoa narrative in social forums' central mobilization discourses; deliberate framing based on external authoritative sources; negotiating framing rooted in the tangential inclusion of the Genoa narrative in the forums' websites; negotiating framing based on the inclusion of external non authoritative sources.

[Figure 2 about here]

Figure 2 maps these competing framing processes onto the sample of social forum websites. Each red dot -labeled as VAR\#\# - stands for a social forum website. As in Figure 1, forum websites toward the top of Figure 2 tended to show a strong involvement with the GSF protest and used deliberative framing. Those toward the bottom showed a weaker involvement by mentioning the Genoa counter-summit in more subtle ways via practices of meaning negotiation. Internal sources of information were most frequently used by social forum websites on the left while involvement generated by the use of external sources of information was the predominant frame for the cases on the right side of the figure. More specifically, forums in the top-left quadrant included the narrative of the Genoa events as a primary reason for protest. Frame inclusion is a strategic process of extension (Benford 
and Snow, 2000: 625) used to integrate a specific element, previously external, within the collective action frame. In fact, social forums using the narrative of the Genoa events to explain their origin and their intents showed the strongest identification with the GSF protest and exploited the injustice frame associated with the repressive events for mobilization purposes.

Forums in the top right quadrant bridged to existing frames generated by external entities. Frame bridging is a strategic process through which schemas of interpretations are borrowed from external sources: "Bridging can occur between a movement and individuals through the linkage of a movement organization with an unmobilized sentiment pool or public opinion cluster" (Benford and Snow, 2000: 624). Social forums activating this framing strategy used external sources to recall the Genoa events but incorporated the information delivered by these sources in their action framing.

Forums in the bottom-left quadrant tended to punctuate certain elements in the narrative of the Genoa events through internal editorials. Another discursive process, frame punctuation involves accenting specific features of an event as more salient than others (Benford and Snow, 2000: 623; Snow and Benford, 1992: 137). It is used to foreground certain aspects of a discussion and background others. Forums using this strategy relied upon internal sources of information, which, nevertheless, were not central to their collective action frame. They shed light on specific features of the narrative of the Genoa events but did not frame them as at the center of their manifesto.

Forums in the bottom-right quadrant articulated meaning through external comments on the events. Frame articulation is a discursive process: it implies the interaction of meanings constructed by different actors (Benford and Snow, 2000: 623). Far from producing absolute and uncontroversial interpretations of problematic issues, frame articulation entails the ongoing interplay of different views. Social forums using this framing technique relied upon 
external sources of information to recall the Genoa days, but again the narrative of the events was not as central to their frame of action as in the first two cases.

The question certainly arises about why each of these different available framing processes would get chosen by particular social forums.

In fact, save for Rifondazione Comunista (extreme-left party) and some Greens, no political party openly agreed with the Italian mobilization for global justice before and after the GSF protest (Reiter et al., 2007: 73-74). The Italian movement for global justice could not rely on alliances with any established members of the polity and had very few opportunities to gain political recognition. In particular, the Italian center-left coalition was never supportive of the GSF and its leaders. Despite the possibilities of interaction, if not collaboration, on common themes of discussion, leftist parties never entirely recognized the Italian movement for global justice as a possible interlocutor. The center-left coalition only partially backed the movement and a wider alliance after July 2001, in criticizing the strategies of protest policing adopted at the counter-summit (Andretta et al., 2002: 170) ${ }^{10}$. The positioning of leftist political parties might be one of the reasons a higher number of Italian social forums activated deliberative and negotiating framing processes (i.e., frame bridging, articulation) via external rather than internal voices; at the time, a direct association with the GSF leaders was likely to lower rather than increase their mobilization potential. Conversely, external sources of information on police repression and victims' testimony could legitimate the adoption of a salient injustice frame of action.

\section{Conclusion}

By focusing on the 2001 anti-G8 summit in Genoa, this study explores the interpretative processes associated with transformative events leading to increased mobilization: tactics of outrage management adopted by state authorities and framing processes activated by protest actors. Investigating such interpretative dimension over ten years after the events allows one 
to exploit both the documentation made available during the many trials opened in the aftermath of the counter-summit and the discursive dimension developed by protest actors in the first years after the events.

In line with the existing literature on transformative events and backfire (Hess and Martin, 2006; Jansen and Martin, 2004; Martin, 2004, 2005, 2007, 2009), the analysis of video documentation, inquiry accounts and academic scholarly work shows that the Italian authorities employed all possible strategies to inhibit public outrage. Cover-ups were perpetuated at different moments, especially by upper rank police officers; protesters were stigmatized by government authorities; early authoritative assessments tended to reframe the violent events as normal protest policing; and activists were intimidated in several occasions, both during the street demonstrations and after arrest. In particular, police brutality was often reinterpreted as legitimate law enforcement.

In terms of social movement framing, the narrative of the Genoa events became an element for discursive interaction among emerging Italian social forums. The memory of the "fatti di Genova" brought a shift back to national issues of democracy and civil rights, readjusting collective action frames to a strictly local target through a strong injustice component. In fact, the adoption of extremely coercive strategies of protest control by public order divisions - and its exposure in media content - generated cultural material for the emergence of a new strong local contraposition between state authorities and protesters that did not lead to a radicalization of violent protest (Andretta et al., 2002: 120-131), but produced a temporary increase of framing potential for backfire mobilization. As Jansen suggests: "specific constructions of the past have a use value for certain actors in the present" and "the ability to "key" the present to the past is a potentially valuable resource" (Jansen 2007: 959). In fact, Italian social movement actors after 2001 acted as "mnemonic agents" (Zamponi 2013) and exploited the memory of the Genoa events to generate renovated collective action frames and 
bolster new mobilization processes. But how did this cognitive dimension develop via the production of specific cultural material? The MDS mapping shows that Italian social forums exploited the narrative of the Genoa events by using online symbolic devices 1) more or less strongly linking the narrative of Genoa 2001 to their activities and 2) generated by the forums themselves or by external sources of information. Via the use of these different symbolic devices, social forums used the narrative of the GSF and its violent repression in framing processes of deliberation and negotiation. In fact, bridging, articulation, punctuation, and extension (via inclusion) are the specific interpretative processes emerging from the use of different online symbolic devices. The MDS analysis also shows that frame bridging and articulation, activated by external sources of information (i.e., sources produced by bodies other than the forum), were most likely to occur. Probably given the lack of endorsement for the GSF from the main Italian political parties of the left - after Genoa 2001 local social forums strategically drew attention to the narrative of violent policing at the counter-summit. External sources of information on police repression and victims' testimonies became then functional to generate deliberative and negotiating framing that were likely to resonate to public opinion and find support from the institutional polity. Meeting with more public's receptivity than the GJM's anti capitalistic arguments, this exclusive focus on violence bolstered framing potential in the short term and produced "mnemonic agency" (Zamponi 2013) for future mobilization but overshadowed the movement's original goals. In fact, while the GJM's collective action frame gradually faded away from the Italian social movement context, the anti-G8 summit became iconic in the Italian history of social contention. This study shows that the exploration of activists' strategic framing in the aftermath of repressive events adds to the analysis of the relationship between repression and mobilization. It does so by drawing attention to the cultural dimension of social movements' agency, an aspect often overlooked in current research on the matter. In particular, by 
applying a cognitive approach to the study of repressive events that have turned transformative, research can shed light on the active role of social movements' activists in the development of interpretive processes that can affect wider publics and mark turning points in a social movement's history.

\section{References}

Andretta, M., Della Porta, D., Mosca, L., and Reiter, H. (2002). Global, Noglobal, Newglobal. Rome: Laterza

Benford, R. D. (1993). Frame disputes within the nuclear disarmament movement. Social Forces 71: 677-701.

Benford, R. \& Snow, D. A. (1992). Master Frames and Cycles of Protest. In: A. D. Morris \& C. McClurg Mueller (Eds.) Frontiers in Social Movement Theory (Pp. 133-15). Yale University Press, New Haven, CT.

Benford, R. D. \& Snow, D. A. (2000). Framing Processes and Social Movements: An Overview and Assessment. Annual Review of Sociology 26: 611-639.

Bennett, L. W. (2003). Communicating Global Activism: Strengths and Vulnerabilities of Networked Politics. Information, Communication \& Society 6:2, 143-168.

Chiesa, G. (2001). G8/Genova. Einaudi, Torino.

Della Porta, D. (1996). Social Movements and the State: Thoughts of the Policing of Protest. In: D. McAdam, J. D. McCarthy \& M. N. Zald (Eds.) Comparative Perspective on Social Movements (pp. 62-96). CUP, Cambridge. . (2005). Multiple Belongings, Tolerant Identities, and the Construction of

"Another Politics": Between the European Social Forum and the Local Social Fora. In: D. Della Porta \& S. Tarrow (Eds.) Transnational Protest and Global Activism edited (pp. 175-202). Rowman \& Littlefield, Oxford. . (2006). Globalization from Below Transnational Activists and Protest 
Networks. University of Minnesota Press, Minneapolis. . (2008). Eventful Protest, Global Conflicts. Distinktion: Scandinavian Journal of Social Theory 17: 27-56.

Della Porta, D. \& Reiter, H. (2006). The Policing of Global Protest: The G8 at Genoa and its Aftermath. In: D. Della Porta, H. Reiter \& A. Peterson (Eds.) The Policing of Transnational Protest (pp. 13-42). Ashgate, Aldershot.

Della Porta, D., Reiter, H. \& Peterson, A. (Eds.) (2006). The Policing of Transnational Protest. Ashgate, Aldershot.

Della Porta, D. \& Tarrow, S. (2001). After Genoa and New York: The Antiglobal Movement, the Police and Terrorism. Items and Issues: Social Science Research Council 2(3-4): $9-11$.

Earl, J. (2011). Political Repression: Iron Fists, Velvet Gloves, and Diffuse Control. Annual Review of Sociology 37(2): 261-84.

Fernandez, L. A. (2008). Policing Dissent. Social Control and the Anti-Globalization Movement. Rutgers University Press, Piscataway, NJ.

Francisco, R. A. (2004). After the Massacre: Mobilization in the Wake of Harsh Repression. Mobilization 9(2): 107-126.

Gamson, W. A. (1992). Talking Politics. CUP, New York.

Gamson, W. A. \& Lasch, K. E. (1983). The Political Culture of Social Welfare Policy. In: S. E. Spiro \& E. Yuchtman-Yaar (Eds.) Evaluating the Welfare State: Social and Political Perspectives (pp. 397-415). Academic Press, New York.

Gamson, W. A. \& Modigliani, A. (1987). The Changing Culture of Affirmative Action.” In: R. G. Braungart \& M. M. Braungart (Eds.) Research in Political Sociology, Vol. 3 (pp. 137-77). JAI Press, Greenwich, CT. (1989). Media Discourse and Public Opinion on Nuclear Power: A 
Constructionist Approach. American Journal of Sociology 95(1): 1-37.

Guadagnucci, L. (2008). Noi della Diaz. Altra Economia, Milano.

Gubitosa, C. (2003). Genova nome per nome. Altra Economia, Milano.

Hess, D. \& Martin, B. (2006). Repression, Backfire and the Theory of Transformative Events. Mobilization 11(1): 249-267.

Jansen, R. S. (2007). Resurrection and Appropriation: Reputational Trajectories, Memory Work, and the Political Use of Historical Figures. American Journal of Sociology 112(4): 953-1007.

Jansen, S. C. \& Martin, B. (2003). Making Censorship Backfire. Counterpoise 7(3): 5-15. Jasper, J. M. (1997). The Art of Moral Protest: Culture, Biography, and Creativity in Social Movements. University of Chicago Press, Chicago.

(2010). Cultural Approaches in the Sociology of Social Movements. In: B.

Klandermans \& C. Rogeband (Eds.) Handbook of Social Movements Across

Disciplines (pp. 59-110). Springer, New York.

(2011). Emotions and Social Movements: Twenty Years of Theory and

Research. Annual Review of Sociology 37:14.1-14.19.

Johnston, H. (2005). Comparative Frame Analysis. In: H. Johnston \& J. A. Noakes (Eds.)

Frames of Protest. Social Movements and the Framing Perspective (pp. 237-255).

Rowman \& Littlefield Publishers, INC, Oxford.

Lucarelli, C. (2009). G8 Cronaca di una battaglia. Einaudi, Torino.

Martin, B. (2004). Iraq Attack Backfire. Economic and Political Weekly 39(16): 1577-1583. (2005). The Beating of Rodney King: The Dynamics of Backfire. Critical Criminology 13(3): 307-326.

(2007). Justice Ignited: The Dynamics of Backfire. Rowman and Littlefield,

Lanham, MD. 
(2009). Managing outrage over genocide: case study Rwanda. Global

Change, Peace \& Security 21(3): 275-290.

McAdam, D. (1999). Political Process and the Development of Black Insurgency 1930-1970. University of Chicago Press, Chicago.

McAdam, D. \& Sewell, W. H. (2001) It's about Time. Temporality in the Study of Social Movements and Revolutions. In: R. R. Aminzade, J. A. Goldstone, D. McAdam, E. J. Perry, W. H. Sewell, S. Tarrow \& C. Tilly (Eds.) Silence and Voice in the Study of Contentious Politics (pp. 89-125) CUP, Cambridge.

McCammon, H. J., Chaudhuri, S, Hewitt, L., Sanders Muse, C. and Newman, H. D. (2008). Becoming Full Citizens: The U.S. Women's Jury Rights Campaigns, the Pace of Reform, and Strategic Adaptation. American Journal of Sociology 113(4): 1104-47.

McLean, P. D. (1998). A Frame Analysis of Favor Seeking in the Renaissance: Agency, Networks, and Political Culture. American Journal of Sociology 104(1): 51- 91.

Noakes, J., \& Johnston, H. (2005). Frame of Protest: A Road Map to a Perspective. In: J. Hank \& J. A. Noakes (Eds.) Frames of Protet. Social Movements and the Framing Perspective (pp. 1-29). Rowman \& Littlefield Publishers, INC., Oxford.

Ortiz, D. G. (2007). Confronting oppression with violence: Inequality, Military Infrastructure and Dissident Repression. Mobilization 12(3): 219-238.

Pan, Z., \& Kosicki, G. (1993). Framing Analysis: An Approach to News Discourse. Political Communication 10 (1): 55-75.

Reiter, H., Andretta, M., Della Porta, D., \& Mosca, L. (2007). The Global Justice Movement in Italy. In: D. Della Porta (Ed.) The Global Justice movement (pp. 52-78). Paradigm, London.

Snow, D. A., Burke Rochford, E., Worden, S. K. \& Benford, R. D. (1986). Frame Alignment Processes, Micromobilization, and Movement Participation. American Sociological 
Review 51: 464-481.

Tarrow, S. (2005). The Dualities of Transnational Contention. Mobilization 10(1): 53-71.

Author removed (2013).

Zamponi, L. (2013). Collective Memory and Social Movements. In: Snow, D.A., della Porta, D., Klandermans, B., McAdam, D. (eds.) The Wiley-Blackwell Encyclopedia of Social and Political Movements. Wiley-Blackwell.

Zuo, J., \& Benford, R. D. (1995). Mobilization processes and the 1989 Chinese democracy movement. Sociological Quarterly 36: 131-156.

\section{Videos}

Ferrario (2001). Le strade di Genova.

Lucarelli (2009). G8 Cronaca di una battaglia.

Verri (2001). Moltitudini.

\section{Websites}

Piazza Carlo Giuliani, http://www.piazzacarlogiuliani.org [Accessed 01 October 2013]

Comitato Verità e Giustizia, http://www.veritagiustizia.it [Accessed 01 October 2013]

Supporto Legale, http://www.supportolegale.org [Accessed 01 October 2013]

Indymedia, www.indymedia.org [Accessed 01 October 2013]

Table 1. Framing Processes

\begin{tabular}{|l|l|}
\hline \multicolumn{2}{|c|}{ Framing processes } \\
\hline Discursive (negotiation) & $\begin{array}{l}\text { articulation } \\
\text { punctuation }\end{array}$ \\
\hline Strategic or alignment (deliberation) & frame bridging, \\
& frame amplification, \\
& frame extension, \\
frame transformation
\end{tabular}

Table 2. Symbolic Devices and their Codes

\begin{tabular}{ll}
\hline & Symbolic Devices \\
\hline Value & Code \\
\hline Press review on GSF protest & PressReviewOnGenoaFacts \\
Letter from Carlo Giuliani’s parents & LetterFromCarlosParents \\
Letter for Carlo Giuliani & LetterForCarlo
\end{tabular}


Article on the release of GSF documentary Testimonies of GSF protest

Link to Piazza Carlo Giuliani website

Link to Verità e Giustizia website

Link to Supporto Legale website

Link to Indymedia website

Editorial on GSF protest

Editorial on after-Genoa events
Documentary

Testimonies

LinkPiazzaCarloGiuliani

LinkVeritaGustizia

LinkSupportoLegale

LinkIndymedia

PieceOnGSF

PieceOnAfterGenoa

Announcement of GSF commemorative events PieceOnDemonstrationForGenoa

Photos of GSF protest and events

Photos

Section on police repression at GSF

PieceOnViolentPolice

GSF injustice in forum's Declaration of Intents FoundationInjustice

GSF protest in forum's Declaration of Intents FoundationProtest

Figure 1. Multidimensional Scaling Plot of Symbolic Devices used in Social Forum

Websites to Recall the Genoa Events

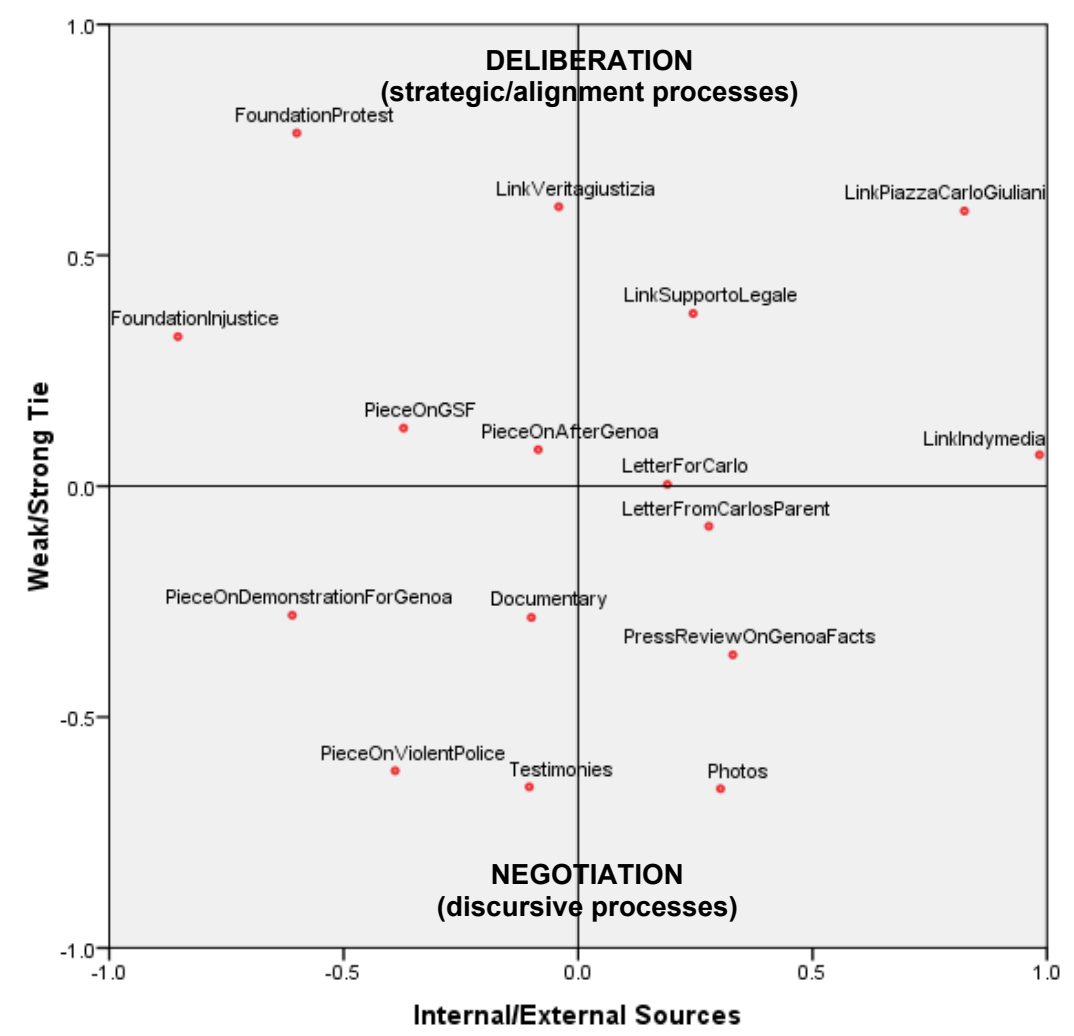

Figure 2. Multidimensional Scaling Plot of Social Forum Websites 


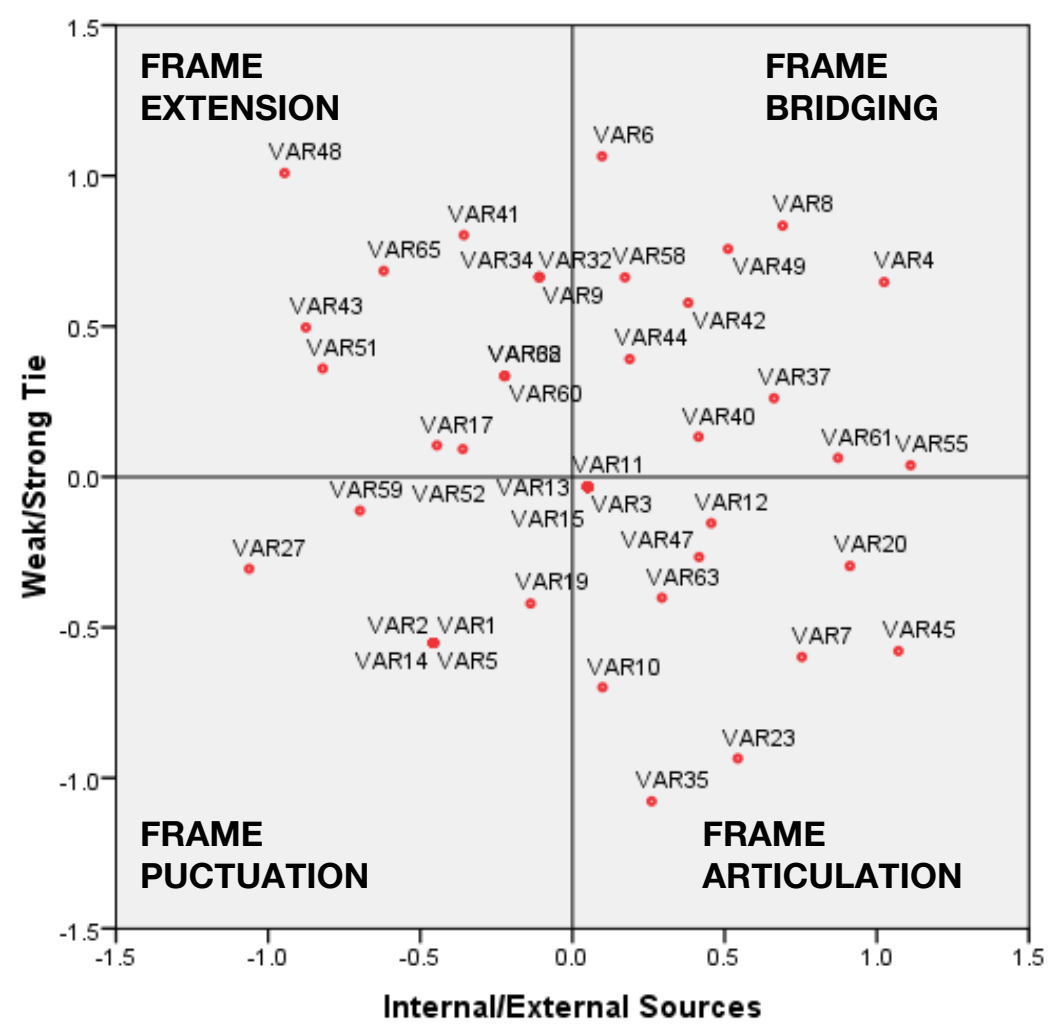




\section{Endnotes}

\footnotetext{
${ }^{1}$ The equivalent term "backlash" is also often used (Francisco 2004, Jasper 2010, Ortiz 2007).

${ }^{2}$ Benford and Snow (2000) also describe "contested processes" but these only characterize cases of internal controversies in social movement discourses.

${ }^{3} 1,187$ different entities signed the Patto di Lavoro, among which were 172 international organizations
} (Gubitosa 2003: 37).

${ }^{4}$ The Black Block is a cluster of anarchist affinity groups. They are declaredly open to police confrontation, blockades and property destruction. They wear black clothing and masks. As Fernandez (2008: 58-59) states: “Adopted by North American anarchists in the late 1990s, the tactic developed in the 1980s in the European autonomous movement [...]. Since then, the Black Block has been common at anti-globalization protests and is common police excuse for targeting the movement."

${ }^{5}$ The narrative of the events presented in this section draws upon academic scholarly work (Della Porta and Reiter 2006); journalistic accounts previously quoted in scholarly work (Gubitosa 2003), first-person journalistic accounts (Chiesa 2001; Guadagnucci 2007), activist knowledge and experience and video documentation used in the trials concerning the Genoa events (Ferrario 2001; Lucarelli 2009). While overall the available data was consistent across the sources, a single inconsistency was found between Gubitosa (2003) and Lucarelli (2009) concerning the first police assault on July 20. In an email exchange with the author, Gubitosa confirmed that Lucarelli's version was more truthful on that specific matter because it was produced when more documentation (i.e., audio recording of police communication on the streets of Genoa) had become available. Hence, in this specific case I endorsed Lucarelli (2009)'s account.

${ }^{6}$ Ansoino Andreassi, State Police vice-chief; Francesco Colucci, the questore of Genoa and Arnaldo La Barbera, head of UCIGOS (central political police).

${ }^{7}$ In June 2005, Vincenzo Canterini, chief of the police mobile division who searched the Pertini-Diaz school, was also promoted. The same happened to Alessandro Perugini, vice-chief of Genoa Digos in 2001, and several other high-ranking police officers involved in the "fatti di Genova" (Guadagnucci 2007: 22-26).

${ }^{8}$ On August 25, 2009 the European Court of Human Rights declared that the death of Carlo Giuliani was not due to excessive use of force by police forces. It was also established that the Italian authorities had not failed to comply with their obligations to protect Giuliani's life. However, it was judged that Italy did not comply with its procedural obligations in connection with the death of Carlo Giuliani (European Court of Human Rights, Press 
Release Issued by Registrar on 25-08-2009). In the Grand Chamber judgment issued on March 24, 2011, the European Court of Human Rights fully absolved Italy of Carlo Giuliani's death. In fact, it definitely dismissed allegations of shortcomings in the organisation and planning of the policing operations at the G8 summit in Genoa and of the lack of an effective investigation into the death of the protester (i.e., violation of articles 2, 3, 6, 13 of the European Convention on Human Rights) (European Court of Human Rights, Press Release Issued by Registrar on 24-03-2011).

${ }^{9}$ On July 19, 2011, Amnesty International published a public statement to condemn the failure of the Italian authorities to ensure effective investigation, and prosecution, of all law enforcement agents involved in human rights violations, including torture: "On the occasion of the tenth anniversary of the 2001 Genoa G8 summit, Amnesty International regrets having to reiterate once again its call for accountability in relation to the human rights violations committed at that time by law enforcement officers, and is concerned that failure to address structural legal and institutional shortcomings may result in impunity. Impunity for abuses such as those committed during this summit is an intolerable stain on Italy's human rights record" (Amnesty International Public Statement, Index: EUR 30/013/2011).

${ }^{10}$ In fact, the lack of support from the institutional polity played a role in the gradual fragmentation of the global justice movement in Italy following the first five years of the after-Genoa backfire mobilisation. 